\title{
The Association Between Antidepressant Effect of SSRIs and Astrocytes: Conceptual Overview and Metaanalysis of the Literature
}

DOI:

10.1007/s11064-020-03225-6

\section{Document Version}

Accepted author manuscript

Link to publication record in Manchester Research Explorer

Citation for published version (APA):

Chen, B., Zhang, M., Ji, M., Gong, W., Chen, B., Zorec, R., Stenovec, M., Verkhratsky, A., \& Li, B. (2021). The Association Between Antidepressant Effect of SSRIs and Astrocytes: Conceptual Overview and Metaanalysis of the Literature. Neurochemical research. https://doi.org/10.1007/s11064-020-03225-6

\section{Published in:}

Neurochemical research

\section{Citing this paper}

Please note that where the full-text provided on Manchester Research Explorer is the Author Accepted Manuscript or Proof version this may differ from the final Published version. If citing, it is advised that you check and use the publisher's definitive version.

\section{General rights}

Copyright and moral rights for the publications made accessible in the Research Explorer are retained by the authors and/or other copyright owners and it is a condition of accessing publications that users recognise and abide by the legal requirements associated with these rights.

\section{Takedown policy}

If you believe that this document breaches copyright please refer to the University of Manchester's Takedown Procedures [http://man.ac.uk/04Y6Bo] or contact uml.scholarlycommunications@manchester.ac.uk providing relevant details, so we can investigate your claim.

\section{OPEN ACCESS}




\title{
The association between antidepressant effect of SSRIs and astrocytes: Conceptual overview and meta-analysis of the literature
}

\author{
Beina Chen ${ }^{1}$, Manman Zhang ${ }^{1}$, Ming $\mathrm{Ji}^{1}$, Wenliang Gong ${ }^{1}$, Binjie Chen ${ }^{1}$, Robert \\ Zorec $^{2,3}$, Matjaž Stenovec ${ }^{2,3}$, Alexei Verkhratsky ${ }^{4,5,6^{*}}$ and Baoman Li ${ }^{1,6^{*}}$ \\ ${ }^{1}$ Practical Teaching Centre, School of Forensic Medicine, China Medical University, \\ Shenyang, People's Republic of China.
}

${ }^{2}$ Celica BIOMEDICAL, Tehnološki park 24, 1000 Ljubljana, Slovenia

${ }^{3}$ Laboratory of Neuroendocrinology-Molecular Cell Physiology, Institute of Pathophysiology, Faculty of Medicine, University of Ljubljana, Zaloška 4, 1000 Ljubljana, Slovenia

${ }^{4}$ Faculty of Biology, Medicine and Health, The University of Manchester, Manchester, UK.

${ }^{5}$ Achucarro Center for Neuroscience, IKERBASQUE, 48011 Bilbao, Spain

${ }^{6}$ Department of Poison Analysis, School of Forensic Medicine, China Medical University, Shenyang, China.

* Corresponding authors:

Prof. Baoman Li, Ph.D., M.D.

Practical Teaching Center, School of Forensic Medicine, China Medical University No. 77, Puhe Street, Shenbei District, Shenyang, P.R. China

Postcode: 110177

Phone: 86(24)31939437

Fax: 86(24) 83282772

Email: bmli@cmu.edu.cn

Prof. Alexei Verkhratsky, Ph.D., M.D.

Faculty of Biology, Medicine and Health, The University of Manchester, Manchester, UK.

Email: Alexej.Verkhratsky@manchester.ac.uk 


\begin{abstract}
Major depressive disorders (MDD) a worldwide psychiatric disease, is yet to be adequately controlled by therapies; while the mechanisms of action of antidepressants are yet to be fully characterised. In the last two decades, an increasing number of studies have demonstrated the role of astrocytes in the pathophysiology and therapy of MDD. Selective serotonin reuptake inhibitors (SSRIs) are the most widely used antidepressants. It is generally acknowledged that SSRIs increase serotonin levels in the central nervous system by inhibiting serotonin transporters, although the SSRIs action is not ideal;. The SSRIs antidepressant effect develops with considerable delay; their efficacy is low and frequent relapses are common. Neither cellular nor molecular pharmacological mechanisms of SSRIs are fully characterised; in particular their action on astrocytes remain underappreciated. In this paper we overview potential therapeutic mechanisms of SSRIs associated with astroglia and report the results of meta-analysis of studies dedicated to MDD, SSRIs and astrocytes. In particular we argue that fluoxetine, the representative SSRI, improves depressive-like behaviours in animals treated with chronic mild stress and reverses depression-associated decrease in astrocytic glial fibrillary acidic protein (GFAP) expression. In addition, fluoxetine upregulates astrocytic mRNA expression of 5-hydroxytriptamin/serotonin ${ }_{2 B}$ receptors $\left(5-\mathrm{HT}_{2 \mathrm{~B}} \mathrm{R}\right)$. In summary, we infer that SSRIs exert their anti-depressant effect by regulating several molecular and signalling pathways in astrocytes.
\end{abstract}

Keywords: astrocyte; major depressive disorder; selective serotonin reuptake inhibitors; GFAP; 5- $\mathrm{HT}_{2 \mathrm{~B}}$ receptors 


\section{Introduction}

Major depressive disorder (MDD) is a widespread psychiatric disease characterised by depressed mood, diminished interests, impaired cognitive function, anhedonia and aberrant sleep [1]. The MDD is associated with substantial alterations in the structure, chemistry, and function of the brain [2]. Studies of depressed patients and preclinical investigations of animal models demonstrated that exposure to various environmental factors, including psychological and physical stress, contribute to pathogenesis of depression and are linked to the aberrant homeostasis in the central nervous system (CNS) [3-6]. Astrocytes are primary homeostatic cells of the CNS, which control multiple aspects of brain physiology at all levels of organisation from molecular to organ [7, 8]. Pathological changes in astrocytes are indispensable part of all neurological and neuropsychiatric disorders [9-12]. Loss of astroglial homeostatic capabilities including deficient metabolic support, impairment of brain microcirculation, aberrant ionostasis and pathological neurotransmission alone or in combination contribute to neuropathology and impaired cognitive functions [13, 14]. Expression of multiple receptors and transporters makes astrocytes potential targets for specific therapy; indeed, astroglial cells respond to many drugs employed to treat diseases of the CNS [15-17], although the underlying mechanisms need further clarification.

Treatment of MDD is based on the monoamine hypothesis, which, however popular, does not fully explain the disease pathophysiology, clinical presentation and mechanisms of therapy [18]. Selective serotonin reuptake inhibitors (SSRIs) are the most commonly prescribed drugs worldwide for the treatment of depressive symptoms of various aetiology [19]. An increase in extracellular concentration of serotonin by inhibition of the serotonin transporter (SERT) has been generally acknowledged as leading mechanism of action of SSRIs. In recent years, however, SSRI interactions with other molecules have been revealed thus extending our understanding of the pharmacotherapy of depression. In particular, SSRIs were found to act as agonists of 5- $\mathrm{HT}_{2 \mathrm{~B}}$ serotonin receptors present in astrocytes [21]. Chronic treatment of astrocytes in vitro with fluoxetine increases expression and molecular editing of the $5-\mathrm{HT}_{2 \mathrm{~B}}$ receptor $[11,16]$. Furthermore, treatment of cultured astrocytes or rodent models of depression with fluoxetine regulates the expression of several astrocytic proteins, such as $\mathrm{S} 100 \mathrm{~B}$ and aquaporin-4 (AQP4) that are related to synaptic plasticity and glymphatic clearance [23].

Systematic evaluation of randomised controlled trials is recognised as the most reliable strategy to learn about the efficacy of drugs. However, there are only a few systematic analyses of animal experiments; while the results obtained from animal experiments are difficult to verify in clinical trials. In addition, there are numerous bias factors in different animal experiments that may mislead translation. Therefore, we performed an in depth meta-analysis of the associations between SSRIs as antidepressants in depression rodent models and astrocytes. 


\section{Astrocytes in major depressive disorder (MDD)}

Astrocytes are main homeostatic cells of the CNS that support the function of individual neurones, as well as nervous tissue and the brain and the spinal cord as an organ. Astrocytes are responsible for metabolic support, molecular homeostasis, synapse formation, nutrition, repair, isolation and as well as in maintaining the blood-brain barrier and glymphatic system [7, 24-27]. Analyses of the human post-mortem brain tissue obtained from patients with depressive disorders have found that the number of astrocytes and expression of GFAP are decreased in the hippocampus, frontal cortex and amygdala [28-31].

Growing evidence supports a key role of astrocytes in MDD [32]. The decrease in the density of astrocytes, expression of GFAP expression and shrinkage of GFAP morphological profiles are well documented in MDD patients [31-34]. These changes, reflecting astroglial impairments, have been observed in many regions of the brain including the dorsolateral prefrontal cortex [35, 36], orbitofrontal cortex [36], subgenual cortex [37], anterior cingulate cortex [38, 39], and amygdala [40]. Similarly, astrocytic density and expression of GFAP were both reduced in the grey matter of mice and rats with depressive-like phenotypes induced by exposure to various types of stress [41, 42]. At the same time animal models of depression were characterized with down-regulation of several bona fide astroglial markers including aquaporin 4, astroglia-specific connexins, astroglial plasmalemmal glutamate transporters and glutamine synthetase [43-45]. Treating animals with astroglia-targeting pharmacological agents, such as inhibitors of gap junctions or glutamate transporters, resulted in development of depressive-like behaviours and anhedonia [46, 47]. In adult rats, ablation of astrocytes by injection of L- $\alpha$-aminoadipic acid, the gliotoxin, into the frontal cortex triggered depressive-like behaviours [48]. Thus, development of depression is associated with prevalence of astroglial atrophy and degeneration, with little signs of astroglial reactivity [30, 49]. Asthenic astrocytes reduce their coverage of synapses, which may substantially affect neurotransmission, in particular glutaminergic, GABA-ergic and monoaminergic, which in turn can contribute to the dysbalance of inhibition and excitation linked to a variety of psychiatric disorders, including depression, anxiety, and schizophrenia [4, 50].

One of the fundamental functions of astrocytes is coordinated supply of the brain tissues with a variety of growth factors expressed and secreted by astroglia [51]. In particular, astrocytes secrete brain-derived neurotrophic factor (BDNF), vascular endothelial growth factor (VEGFR) and fibroblast growth factor 2 (FGF2) [52-54]. Of note, treatment with fluoxetine increases BDNF in astrocytes, however serotonin at $100 \mu \mathrm{M}$ is ineffective, thus indicating that effects of fluoxetine on BDNF levels are linked to SERT [55]. At the same time SSRIs up-regulate astrocytic synthesis of BDNF, which had anxiolytic effects in mice [56]. Astroglial secretion of BDNF promotes synaptic plasticity by enhancing the expression of synaptic vesicle proteins [57]. In hippocampus, BDNF-dependent the synaptic and structural plasticity is 
involved in the pharmacological effects of fluoxetine to improve depressive-like behaviours [56].

Another important part of MDD pathogenesis is associated with neuroinflammation as well as with systemic inflammation $[58,59]$. The chronic stress by itself affects the inflammatory pathways in the brain; in particular exposure to stress stimulates the synthesis and increases brain levels of pro-inflammatory cytokines, including tumour necrosis factor-alpha (TNF- $\alpha$ ), interleukin-6 (IL-6), interleukin-1 $\beta$ (IL-1 $\beta$ ) and interferon- $\alpha$ (IFN- $\alpha)[60]$. At the same time, the plasma concentration of pro-inflammatory cytokines is increased in patients with MDD [61]. Moreover, the neuroinflammation induced by post-traumatic stress disorders activates astrocytes by up-regulating the expression and release of CC-chemokine ligand 2 (CCL2), which promotes the extravasation and infiltration of monocytes into the cerebral parenchyma [62]. Similarly, increased astroglial expression of CCL2 was discovered in the cortex of post-mortem brain of the suicide patients with MDD [63]. In astrocytes, the release of ATP can stimulate the expression of CCL2 through $\mathrm{P}_{2} \mathrm{X}_{7}$ purinergic receptors $\left(\mathrm{P} 2 \mathrm{X}_{7} \mathrm{R}\right)[64]$. At the same time stimulation of $\mathrm{CCL} 2$ and $\mathrm{P} 2 \mathrm{X}_{7} \mathrm{R}$ can boost astroglial IL-1 $\beta$ release and activate inflammasome both associated with depression-like behaviours [65], likewise interfering the sleep quality [66].

\section{Meta-analysis of the literature data}

Fluoxetine as the representative SSRIs can regulate functions of astrocytes, although some details remain uncertain. For example, it is not confirmed whether fluoxetine affects the level of GFAP or the number of astrocytes in MDD; whether there is an astroglial target specifically regulated by fluoxetine; or whether the behavioural tests applied for the identification of depressive-like behaviours are consistent.

\section{Study selection and quality assessment}

A total of 359 articles were initially identified, and after removing duplicates and screening study titles and abstracts, 38 articles that matched inclusion criteria (see methods in supplementary materials) remained for full-text screen. Ten articles were included in the list for the meta-analysis [67-76]. The article selection process is shown on Fig. 1. Among the 10 included studies, eight used mice and two used rats. In addition, from these articles, eight experiments reported behavioural outcomes, including sucrose preference test, forced swimming test, and tail suspension test. Five studies reported the expression levels of GFAP and the number of astrocytes, and two studies reported the influence of fluoxetine on 5- $\mathrm{HT}_{2}$ receptors. Detailed characteristics of the articles are shown in Table 1. Methodological quality of included studies, which were assessed using SYRCLE's risk of bias tool and CAMARADES checklist for study quality as described in [77] are shown in Table 2, indicating overall sufficient quality of the studies. 


\section{Data analysis}

GFAP

The overall meta-analysis included 5 studies that evaluated GFAP expression. One of them [68] was excluded after heterogeneity analysis. The pooled result showed a significant difference between these control and depressed groups, indicating that GFAP expression decreased in depression-like rodents (four studies, pooled SMD = 4.49, 95\% Cl: 2.85 to $6.13 ; p<0.05$ ) (Fig. $2 \mathrm{~A}$ ). The pooled result also demonstrated that fluoxetine treatment significantly increased GFAP expression (four studies, pooled $\mathrm{SMD}=-2.66,95 \% \mathrm{Cl}:-3.42$ to $-1.90 ; p<0.05)$ (Fig. $2 \mathrm{~B}$ ).

\section{Astrocytes numbers}

Changes in the number of astrocytes were reported in 3 articles. A single paper reported the number of astrocytes in the local area of hippocampus which was significantly different from other studies, so it was not included in the calculation. The number of astrocytes in the brains of depressed mice was smaller when compared to the control group (two studies, pooled $\mathrm{SMD}=8.78,95 \% \mathrm{Cl}$ : 6.82 to $10.75 ; p<0.05$ ) (Fig. 3A). Treatment with fluoxetine significantly increased the number of astrocytes in mice models with depression (two studies, pooled SMD $=-4.94,95 \% \mathrm{Cl}:-7.22$ to $-2.66 ; p<0.05)$ (Fig. 3B).

\section{$\underline{5-\mathrm{HT}_{2}}$ receptor}

Two articles reported changes in the levels of expression of 5- $\mathrm{HT}_{2}$ receptors in the mouse brains. Combined results showed that, compared with the control group, the mRNA expression of 5- $\mathrm{HT}_{2 \mathrm{~B}}$ receptors significantly increased in the fluoxetine-treated group (two studies, pooled $\mathrm{MD}=-0.53,95 \% \mathrm{Cl}$ : -0.60 to $-0.46 ; p$ $<0.05$ ) (Fig. 4A). However, there was no significant difference in mRNA expression of $5-\mathrm{HT}_{2 \mathrm{C}}$ receptors in mice (two studies, pooled $\mathrm{MD}=-0.05,95 \% \mathrm{Cl}:-0.11$ to 0.00 ; $p=0.06$ ) (Fig. 4B).

\section{$\underline{\text { Behavioural tests }}$}

Eight articles reported behavioural outcomes in mice. Sucrose preference was invariably increased after treatment with fluoxetine in depression rodent models (five studies, pooled SMD $=-2.60 ; 95 \% \mathrm{Cl}:-4.07$ to $-1.41 ; p<0.05)$ (Fig. 5A), although there was significant heterogeneity $\left(\mathrm{p}<0.05 ; \mathrm{I}_{2}=80 \%\right)$. Therefore, subgroup analyses were performed. Five studies were divided into two subgroups according to their different recording measurement units of sucrose preference. One subgroup included three studies which reported sucrose preference by percentage of sucrose, and the other subgroup included two studies which reported relative sucrose intake in terms of $\mathrm{g} / \mathrm{kg}$. The results of subgroup analyses show a consistent trend of increased sucrose preference between the depressive rodent group and fluoxetine treatment group with low heterogeneity within each of subgroups. High heterogeneity existed between two subgroups, which may result from different recording methods used to quantify sucrose preference. The immobility times of forced swimming tests (five studies, 
pooled $\mathrm{MD}=56.32,95-\mathrm{Cl}: 39.83$ to $72.81 ; p<0.05)($ Fig. $5 \mathrm{~B})$ and tail suspension tests (three studies, pooled $\mathrm{MD}=73.24,95 \% \mathrm{Cl}$ : 68.34 to $79.77 ; p<0.05$ ) (Fig. $5 \mathrm{C}$ ) decreased after administration of fluoxetine. The pooled result of forced swimming tests similarly exhibited high level of heterogeneity.

\section{Meta-analysis conclusion}

According to the meta-analysis of articles which studied the effects of SSRIs on astrocytes in the rodent depression model the following can be concluded: (i) fluoxetine could recover depression-induced decrease in the expression of GFAP and in the number of astrocytes (Fig. 2 and Fig. 3); (ii) fluoxetine selectively increased the mRNA expression of $5-\mathrm{HT}_{2 \mathrm{~B}}$ receptors in astrocytes, but had no influence on the mRNA expression of 5-HT2 $\mathrm{H}_{2 \mathrm{C}}$ receptors (Fig. 4); (iii) Through a high degree of inter-study heterogeneity existed in the pooled results of sucrose preference and forced swimming test, these heterogeneity was mainly due to the different measured patterns or various measurement units (Fig. 5).

\section{SSRIs and astrocytes}

The universally acknowledged mechanism of anti-depressant action of SSRIs is an inhibition of serotonin uptake, which increases the level of bioavailable 5-HT in the brain, thereby enhancing serotonergic neurotransmission [78]. The mammalian family of serotonin receptors family includes seven members (5-HT $\mathrm{H}_{1-7}$ receptors), out of which $5-\mathrm{HT}_{1 \mathrm{~A}-1 \mathrm{~F}}, 5-\mathrm{HT}_{2 \mathrm{~A}-2 \mathrm{C}}, 5-\mathrm{HT}_{6}, 5-\mathrm{HT}_{7}$ subunits are expressed in astrocytes $[75$, 79-82]. In experiments in vitro, stimulation of $5-\mathrm{HT}_{1 \mathrm{~A}}$ receptors was shown to increase the mRNA expression of $\mathrm{Ca}^{2+}$-binding protein $\mathrm{S} 100 \mathrm{~B}$ as well as its release from astrocytes [83]. At the same time higher level of serum S100B was measured in patients with MDD compared with healthy subjects [84, 85]. Transgenic mice overexpressing S100B show depressive-like behaviours, which can be alleviated by inhibitors of 5- $\mathrm{HT}_{7}$ receptors [86]. An atypical antipsychotic drug olanzapine augments fluoxetine-induced increase of extracellular 5-HT levels and rescues depressant-like behaviours by inhibiting $5-\mathrm{HT}_{6}$ receptors through decreasing the firing frequency of $\gamma$-aminobutyric acid GABA-ergic neurones in dorsal raphe nucleus [87]. Trazodone, a triazolopyridine derivative, can exert neuroprotective roles by activating $5-\mathrm{HT}_{1 \mathrm{~A}}$ receptors, however it also inhibits $5-\mathrm{HT}_{2 \mathrm{~A} / 2 \mathrm{C}}$ receptors in human astrocytes, and stimulates the ERK/AKT/c-Jun N-terminal kinases signalling pathway [88].

The 5- $\mathrm{HT}_{2 \mathrm{~B}}$ receptors, similarly to the majority of other serotonin receptors, are Gq-coupled 7-transmembrane domains metabotropic receptors expressed in astrocytes [80]. The SSRIs were shown to selectively stimulate astroglial $5-\mathrm{HT}_{2 \mathrm{~B}}$ receptors, which effect is linked to anti-depressive potency of these drugs $[89,90]$. In primary mouse cultured astrocytes acute treatment with fluoxetine (5-10 $\mu \mathrm{M}, 20$ to $40 \mathrm{~min})$ induces the phosphorylation of extracellular regulated kinases 1 and $2\left(\mathrm{ERK}_{1 / 2}\right)$ [89]. Fluoxetine-induced ERK $\mathrm{E}_{1 / 2}$ phosphorylation can be inhibited by the 5-HT 2 antagonist SB204741, but not by $5-\mathrm{HT}_{2 \mathrm{~A}}$ selective receptors antagonist M100901, or $5-\mathrm{HT}_{2 \mathrm{C}}$ 
selective receptors antagonist SB242084; inhibition of the expression of 5- $\mathrm{HT}_{2 \mathrm{~B}}$ receptors by siRNA duplex chains abolishes the effect of fluoxetine on the activation of $E_{R K} / 2$ [89]. This indicates that the effect of fluoxetine to increase $E K_{1 / 2}$ phosphorylation is mediated by $5-\mathrm{HT}_{2 \mathrm{~B}}$ receptor. Astroglial $5-\mathrm{HT}_{2 \mathrm{~B}}$ receptors are coupled with $\mathrm{G}_{\mathrm{q} / 11}$ protein [91]; activation of 5-HT $2 \mathrm{~B}$ receptors stimulates phospholipase C (PLC), which produces diacylglycerol (DAG) and inositol 1,4,5-trisphosphate $\left(\mathrm{InsP}_{3}\right)$ by hydrolysing phosphatidyl-inositol 4,5-bisphosphate $\left(\mathrm{PIP}_{2}\right)$. The $\mathrm{Ins}_{3}$, in turn, evokes $\mathrm{Ca}^{2+}$ release from the endoplasmic reticulum thus generating $\mathrm{Ca}^{2+}$ signals, which form the basis of astroglial excitability [92, 93]. Astroglial $\mathrm{Ca}^{2+}$ signals, in particular, enhance the activity of $\mathrm{Zn}$-dependent metalloproteinases by stimulating protein kinase $\mathrm{C}$ (PKC). Activated metalloproteinases can hydrolyse heparin-binding epidermal growth factor (EGF)-like growth factor (HB-EGF) and promote its shedding from the membrane [94]. The HB-EGF transactivates epidermal growth factor receptor (EGFR) [95], induces receptor tyrosine kinases phosphorylation, and ultimately regulates two signalling pathways: the MEK/ERK and PI3K/AKT [96]. The 5-HT $2 \mathrm{~B}$ receptors-induced ERK $1 / 2$ phosphorylation can increase mRNA and protein expression level of $c$-fos [89, 97], with the latter regulating expression of other bioactive factors including $\mathrm{Ca}^{2+}$-dependent phospholipase A2 (cPLA2) and BDNF [98, 99].

Of note, chronic and acute treatments with different concentrations of fluoxetine produce distinct pharmacological actions. In particular, fluoxetine shows biphasic regulatory effects on caveolin-1/PTEN/PI3K/AKT/GSK-3 $\beta$ pathway in astrocytes [97]. Acute treatment with fluoxetine at low concentration $(0.5 \mu \mathrm{M}-1 \mu \mathrm{M})$ activates $5-\mathrm{HT}_{2 \mathrm{~B}}$ receptor, with subsequent stimulation of $\mathrm{Src}$ that triggers $\mathrm{PI} 3 \mathrm{~K} / \mathrm{AKT}$ signalling pathway which induces phosphorylation of EGFR and AKT. This leads to a subsequent down-regulations of expression of $c$-fos and caveolin-1 (Cav-1) in primary cultured astrocytes [97]. Next, Cav-1 decreases membrane content of phosphatase and tensin homologue (PTEN) and induces the phosphorylation of PI3K and glycogen synthase kinase $3 \beta$ (GSK-3 $\beta$ ), which ultimately inhibits activity of the latter [97]. Astrocytes treatment with high concentrations of fluoxetine $(5 \mu \mathrm{M}-10 \mu \mathrm{M})$ up-regulates $c$-fos through increasing phosphorylation of $\mathrm{ERK}_{1 / 2}$, with subsequent increase in the expression of Cav-1 that activates the PTEN/PI3K/AKT/GSK-3 $\beta$ pathway [97]. The GSK-3 $\beta$ is one of the key kinases that participates in the regulation of glycogen phosphorylation. Impaired activity of GSK is related to MDD; it was reported that the phosphorylation of GSK-3 $\beta$ is lower in the brain of MDD patients [99]. An increase in GSK-3 $\beta$ activity has been found in prefrontal cortex and in platelets of depressed patients [100-102], while the gene expression of GSK-3 $\beta$ is up-regulated in the frontal cortex, in the raphe, and in the hippocampus of rat model of depression [103].

Chronic treatment with fluoxetine increases the mRNA and protein expression of cPLA2 by stimulating $5-\mathrm{HT}_{2 \mathrm{~B}}$ receptor [98]. The up-regulation of cPLA2 is enzyme-specific since neither secretory PLA2 (sPLA2) nor intracellular PLA2 
(iPLA2) respond to fluoxetine [98]. The majority of cPLA2 in the grey matter is located in astrocytes [104]; the cPLA2 is a $\mathrm{Ca}^{2+}$-sensitive cytosolic enzyme that acts as an activator of the release of arachidonic acid (AA). The AA is linked with pathophysiology of depression through its effects on serotonin transports [105]. Chronic treatments with fluoxetine can mediate post-translational editing of some genes at different concentrations. Another relevant pathway is associated with the adenosine deaminase acting on RNA (ADAR) signalling cascade. The ADAR2 that catalyzes the conversion of adenosine to inosine is highly expressed in astrocytes [106]. Treatment of astrocytes for three days with fluoxetine at high concentration (10 $\mu \mathrm{M})$ increases both mRNA and protein expression of ADAR2 by stimulating $5-\mathrm{HT}_{2 \mathrm{~B}}$ receptors. The up-regulated expression of ADAR2 alleviates the functions of kainate and 5- $\mathrm{HT}_{2 \mathrm{~B}}$ receptors through RNA editing in cultured astrocytes [107, 108]. In contrast, chronic treatments with low concentration $(1 \mu \mathrm{M})$ of fluoxetine, decreases the expression of ADAR2, thus increasing the activation of $5-\mathrm{HT}_{2} \mathrm{C}$ receptors through the suppressed RNA editing [109].

\section{Astrocytes in MDD associated neurological disorders}

Newly revealed antidepressant effects of fluoxetine linked to astrocytes have been extensively studied in the recent decade; these new findings may clarify the relationships between MDD and other neurological diseases, such as alcoholism, sleep disturbance and Alzheimer's disease. Chronic administration alcohol decreases the release of ATP from astrocytes by increasing the expression of ADAR2, while the latter can inhibit 5- $\mathrm{HT}_{2 \mathrm{C}}$ receptors by RNA editing; this in turn, results in the decreased 5- $\mathrm{HT}_{2 \mathrm{C}}$ receptor-mediated ATP release from astrocytes [109]. Diminished astroglial ATP secretion can be associated with the depressive-like behaviours [110]. Fluoxetine selectively stimulates astrocytic 5- $\mathrm{HT}_{2 \mathrm{~B}}$ receptors and activates the downstream Src/EGFR/PI3K/AKT/c-fos signalling cascade thus decreasing the expression of ADAR2 upregulated by alcohol consumption [109]. Meanwhile, in vivo, fluoxetine improves the depressive- and anxiety-like behaviours caused by chronic alcohol administration; furthermore, fluoxetine can decrease the alcohol preference in mice models of chronic alcohol addiction [109].

Sleep disorders and chronic insomnia in particular, are strongly associated with MDD $[99,111]$, although the pathological mechanism underlying this association remains to be fully characterised. Our recent studies analysed possible mechanisms linking anti-depressant effects of fluoxetine to the depressive like behaviours induced by sleep deprivation $[99,112]$. Sleep deprivation could trigger depressive-like behaviour by activating nucleotide-binding domain and leucine-rich repeat protein-3 (NLRP3) inflammasome and by decreasing the level of BDNF in astrocytes [99]. Astrocytic $5-\mathrm{HT}_{2 \mathrm{~B}}$ receptors seem to be the key molecule involved in sleep deprivation-induced depression and the mechanism of action of antidepressants [112, 113]. Firstly, chronic sleep deprivation induced the stimulation of NLRP3 inflammasome in astrocytes requires $\mathrm{P}_{2} \mathrm{X}_{7}$ receptors mediated inhibition of signal transducer and activator of 
transcription 3 (STAT3). Fluoxetine can alleviate activation of NLRP3 inflammations by inducing phosphorylation of $\mathrm{ERK}_{1 / 2}$ and AKT to re-activate STAT3 [99]. Fluoxetine also activates, by $5-\mathrm{HT}_{2 \mathrm{~B}}$ receptors mediated mechanism, the $\mathrm{ERK}_{1 / 2}$ and AKT cascades in astrocytes [107, 114]. However, sleep deprivation down-regulates the expression of astroglial 5- $\mathrm{HT}_{2 \mathrm{~B}}$ receptors through activation of $\mathrm{P}_{2} \mathrm{X}_{7}$ purinoceptors [113]. In contrast, leptin up-regulates astrocytic 5- $\mathrm{HT}_{2 \mathrm{~B}}$ receptors by stimulating JAK2/STAT3 and augments the anti-depressive effects of fluoxetine [99].

As has been already mentioned, BDNF is implicated in the pathogenesis of the MDD [115]. Astrocytes are essential for regulating neuronal morphology through BDNF release [116], while metabolic disturbances or reduced expression of BDNF induced by chronic stress impair neuroplasticity [117]. Chronic sleep deprivation decreases protein expression of BDNF [99]. Fluoxetine alleviates depressive-like behaviours and reverses the decreased BDNF release induced by sleep deprivation by stimulating 5- $\mathrm{HT}_{2 \mathrm{~B}}$ receptors [99]. In experiments in vivo, fluoxetine increased the expression of BDNF by stimulating 5-HT $2 \mathrm{~B}$ receptors-mediated phosphorylation of $\mathrm{ERK}_{1 / 2}$ and $c-f o s$ [99]. Similarly, fluoxetine significantly up-regulates the phosphorylation of ERK and the mRNA expression level of BDNF in human astrocytes [88].

In addition, MDD is a high risk factor for the increased occurrence of Alzheimer's diseases (AD), and SSRIs can obviously improve the depressive symptoms and daily activities of AD patients $[118,119]$. However, the potential pathogenetic link between $\mathrm{MDD}$ and $\mathrm{AD}$ is still unclear. Our recent studies reveal the potential pathological mechanism common to MDD and AD, associated with the dysfunction of glymphatic system [112, 120]. Chronic stress down-regulates AQP4 expression in astrocytes in cortex and hippocampus and leads to glymphatic dysfunction [23]. This dysfunction of glymphatic clearance affects brain microenvironment and may instigate neurotoxicity through suppressed removal of pathological proteins such as $\beta$-amyloid [121]. Glymphatic systems dysfunction caused by chronic unpredictable mild stress (CUMS) promotes accumulation of endogenous and exogenous $\beta$-amyloid in neurones, while fluoxetine improves the efficacy of the glymphatic pathway by increasing AQP4 expression [23]. In addition, AQP4 deficiency impairs learning and memory. These results may hint at the possible mechanism related to depression with cognitive dysfunction and indicate a potential therapeutic relevance of AQP4. Our recent study reports that iron overload can aggravate the depressive-like behaviours induced by CUMS and trigger the cognitive impairments, resulted from the over-dose of iron-induced deficiency of the glymphatic system [119]. Furthermore, there are some suggestions indicating that AQP4 is linked to the therapeutic effects of SSRIs in depression [121]. Genetic deletion of AQP4 abolishes the anxiolytic and anti-depressive effects of fluoxetine [121]. Similarly, fluoxetine requires AQP4 to modulate the morphological plasticity of astrocyte processes [122]. 


\section{Conclusion}

Here we overviewed the contribution of astrocytes to the pathological mechanism of MDD and the pharmacological mechanisms of SSRIs in vivo and in vitro. We presented the data showing the astrocyte-related effects of fluoxetine that restores astroglial density and GFAP which are both suppressed in animal models of depression. Fluoxetine selectively increases the mRNA and protein expression of $5-\mathrm{HT}_{2 \mathrm{~B}}$ receptors in astrocytes, but does not affect the expression of 5- $\mathrm{HT}_{2} \mathrm{C}$ receptors. There is also experimental evidence suggesting the existence of astroglial mechanisms linking MDD with other neurological diseases, such as AD, sleep disorders and alcoholism. In summary, astroglial 5- $\mathrm{HT}_{2 \mathrm{~B}}$ receptors play a key role in the pathophysiology of MDD and in the therapeutic effects of SSRIs. In addition, fluoxetine-dependent activation of astrocytic 5- $\mathrm{HT}_{2 \mathrm{~B}}$ receptors transactivates EGFR and recruits $\mathrm{MEK} / \mathrm{ERK}_{1 / 2}$ and $\mathrm{PI} 3 \mathrm{~K} / \mathrm{AKT}$ signalling cascades, which regulate the expression and function of cPLA2, ADAR2, and AQP4. The sleep deprivation-induced selective downregulation of astroglial $5-\mathrm{HT}_{2 \mathrm{~B}}$ receptors and BDNF may contribute to pathological relationship between sleep disturbance and MDD. Furthermore, the pathophysiology of MDD is also the high risk factor for the occurrence of neurodegenerative diseases. The decrease of AQP4 and the circulation of glymphatic system reduced by chronic stress may create susceptible pathological micro-environments for the occurrence of AD.

\section{Acknowledgements}

This work was supported by the National Natural Science Foundation of China, BL [grant number 81871852]; LiaoNing Revitalization Talents Program, BL [grant number XLYC1807137], the Scientific Research Foundation for Returned Scholars of Education Ministry of China, BL [grant number 20151098], LiaoNing Thousands Talents Program [grant number 202078] and "ChunHui" Program of Education Ministry of Liaoning [grant number 2020703]. R. Zorec is acknowledging the funding by the Slovenian Research Agency [grant number P3 310]. 


\section{Figure legends}

Figure 1. Study identification and selection progress in the meta-analysis. By searching PubMed and Embase, a total of 359 articles were initially identified. After screening title and abstract of studies and removing duplicates, 38 studies were remained for full-text review. Our study excluded 28 studies according to our inclusion criteria, ten articles were finally included in meta-analysis.

Figure 2. Meta-analysis on the expression of GFAP in rodent built with or without depression model and the effects of fluoxetine on rodent depressive models. The zero vertical line represents no difference between two groups. The area of each green point represents its contribution to meta-analysis. Horizontal lines indicate $95 \%$ confidence intervals of the estimate. The black square point represents pooled effect of all included studies in forest plot.

A: Forest plot showing GFAP expression in healthy and depressed rodents. Points located at the positive side indicate reduced expression of GFAP.

B: Forest plot showing GFAP expression in depressed rodents treated with fluoxetine. Points located at the negative side indicate increase in expression of GFAP. P value less than 0.05 denotes statistical significance.

Figure 3. Meta-analysis of astrocyte numbers of depressive rodent models with or without fluoxetine treatment. The solid vertical line represents pooled effect size is zero. The area of each green point represents its contribution to meta-analysis. Horizontal lines indicate $95 \%$ confidence intervals of the estimate.

Figure 4. Forest plot with all included studies of 5- $\mathrm{HT}_{2}$ receptors of rodent depressive models treated with or without fluoxetine. The solid vertical line of zero represents no difference between two groups. The area of each green point represents its contribution to meta-analysis. Horizontal lines indicate $95 \%$ confidence intervals of the estimate. The black square point represents pooled effect of all included studies in forest plot.

A: Forest plot of the mRNA expression of 5- $\mathrm{HT}_{2 \mathrm{~B}}$ receptors. Points located at the negative side indicate increased mRNA expression of 5- $\mathrm{HT}_{2 \mathrm{~B}}$ receptors in depressive-like rodent treated with fluoxetine.

B: Forest plot of the mRNA expression of $5-\mathrm{HT}_{2 \mathrm{C}}$ receptors. Points located at the negative side indicate increased mRNA expression of $5-\mathrm{HT}_{2 \mathrm{C}}$ receptors in rodent depressive model treated with fluoxetine, while points at the positive side indicate decreased mRNA expression of 5- $\mathrm{HT}_{2} \mathrm{C}$ receptors in depressive model treated with fluoxetine. $\mathrm{P}$ value less than 0.05 denotes statistical significance.

Figure 5. Meta-analysis on behavioural test of depressive rodent models with or without fluoxetine treatment.

A: Forest plot of sucrose preference.

B: Forest plot of forced swimming test. 
C: Forest plot of tail suspension test. The solid vertical line represents pooled effect size is zero. The area of each green point represents its contribution to meta-analysis. Horizontal lines indicate $95 \%$ confidence intervals of the estimate.

Figure 6. Astroglial 5- $\mathrm{HT}_{2 \mathrm{~B}}$ receptors and pathogenesis of depression. Astrocytic $5-\mathrm{HT}_{2 \mathrm{~B}}$ receptors play a key role in the pathological mechanisms of sleep deprivation-induced depressive-like behaviours and contribute to action of SSRI antidepressants. Chronic sleep deprivation decreases BDNF levels and instigates activation of NLRP3 inflammasome, which both contribute to the development of depressive-like behaviours. Sleep deprivation suppresses activation of AKT and STAT3, while indirectly increasing the activity of GSK-3 $\beta$, which activates of NLRP3 inflammasome. Administration of fluoxetine can increase the expression of BDNF by stimulating $\mathrm{ERK}_{1 / 2}-c f o s$ signalling pathway in astrocytes. In addition, fluoxetine can also increase the phosphorylation of STAT3 by stimulating ERK $_{1 / 2}$ or AKT, to suppress the activation of NLRP3 inflammasome. Furthermore, leptin augments the anti-depressant effects of fluoxetine by increasing the expression of 5- $\mathrm{HT}_{2 \mathrm{~B}}$ receptors through activation of JAK2-STAT3 cascade. Chronic sleep deprivation selectively decreases the expression of astroglial 5- $\mathrm{HT}_{2 \mathrm{~B}}$ receptors through $\mathrm{P}_{2} \mathrm{X}_{7}$ receptors-mediated inhibition of AKT phosphorylation, which again converge into depressive-like behaviour. 


\section{References}

[1] Malhi GS, Mann JJ (2018) Depression. Lancet 392:2299-2312.

[2] Maletic V, Robinson M, Oakes T, Iyengar S, Ball SG, Russell J (2007) Neurobiology of depression: an integrated view of key findings. Int J Clin Pract 61:2030-40.

[3] Slavich GM, Irwin MR (2014) From stress to inflammation and major depressive disorder: a social signal transduction theory of depression. Psychol Bull 140: $774-815$.

[4] Stenovec M, Li B, Verkhratsky A, Zorec R (2020) Astrocytes in rapid ketamine antidepressant action. Neuropharmacology 173:108158.

[5] Belleau EL, Treadway MT, Pizzagalli DA (2019) The Impact of Stress and Major Depressive Disorder on Hippocampal and Medial Prefrontal Cortex Morphology. Biol Psychiatry 85:443-453.

[6] Dong L, Li B, Verkhratsky A, Peng L (2015) Cell type-specific in vivo expression of genes encoding signalling molecules in the brain in response to chronic mild stress and chronic treatment with fluoxetine. Psychopharmacology (Berl) 232:2827-2835.

[7] Verkhratsky A, Nedergaard M (2018) Physiology of Astroglia. Physiol Rev. 98:239-389.

[8] Verkhratsky A, Nedergaard M (2016) The homeostatic astroglia emerges from evolutionary specialization of neural cells. Philos Trans R Soc Lond B Biol Sci. $371: 20150428$.

[9] Verkhratsky A, Rodríguez JJ, Steardo L (2014) Astrogliopathology: a central element of neuropsychiatric diseases? Neuroscientist 20:576-588.

[10]Verkhratsky A, Zorec R, Parpura V (2017) Stratification of astrocytes in healthy and diseased brain. Brain Pathol 27:629-644.

[11]Peng L, Verkhratsky A, Gu L, Li B (2015) Targeting astrocytes in major depression. Expert Rev Neurother 15:1299-1306.

[12]Czeh B, Fuchs E, Flugge G (2013) Altered glial plasticity in animal models for 
mood disorders. Curr Drug Targets 14:1249-1261.

[13] Verkhratsky A, Ho MS, Vardjan N, Zorec R, Parpura V (2019) General Pathophysiology of Astroglia. Adv Exp Med Biol 1175:149-179.

[14] Vainchtein ID, Molofsky AV (2020) Astrocytes and Microglia: In Sickness and in Health. Trends Neurosci 43:144-154.

[15]Rivera AD, Butt AM (2019) Astrocytes are direct cellular targets of lithium treatment: novel roles for lysyl oxidase and peroxisome-proliferator activated receptor-gamma as astroglial targets of lithium. Transl Psychiatry 9:211.

[16]Peng L, Song D, Li B, Verkhratsky A (2018) Astroglial 5-HT2B receptor in mood disorders. Expert Rev Neurother 18:435-442.

[17]Zhao Y, Lin Z, Chen L, Ouyang L, Gu L, Chen F, Zhang Q (2018) Hippocampal astrocyte atrophy in a mouse depression model induced by corticosterone is reversed by fluoxetine instead of benzodiazepine diazepam. Prog Neuropsychopharmacol Biol Psychiatry 83:99-109.

[18]Boku S, Nakagawa S, Toda H, Hishimoto A (2018) Neural basis of major depressive disorder: Beyond monoamine hypothesis. Psychiatry Clin Neurosci $72: 3-12$

[19]Jakubovski E, Varigonda AL, Freemantle N, Taylor MJ, Bloch MH (2016) Systematic Review and Meta-Analysis: Dose-Response Relationship of Selective Serotonin Reuptake Inhibitors in Major Depressive Disorder. Am J Psychiatry. $173: 174-183$.

[20]Hertz L, Rothman DL, Li B, Peng L (2015) Chronic SSRI stimulation of astrocytic 5- $\mathrm{HT}_{2 \mathrm{~B}}$ receptors change multiple gene expressions/editings and metabolism of glutamate, glucose and glycogen: a potential paradigm shift. Front Behav Neurosci 9:25.

[21]Hertz L, Song D, Li B, Du T, Xu J, Gu L, Chen Y, Peng L (2014) Signal Transduction in Astrocytes during Chronic or Acute Treatment with Drugs (SSRIs, Antibipolar Drugs, GABA-ergic Drugs, and Benzodiazepines) Ameliorating Mood Disorders. J Signal Transduct 2014:593934.

[22]Bock N, Koc E, Alter H, Roessner V, Becker A, Rothenberger A, Manzke T (2013) 
Chronic fluoxetine treatment changes S100B expression during postnatal rat brain development. J Child Adolesc Psychopharmacol 23:481-489.

[23]Xia M, Yang L, Sun G, Qi S, Li B (2017) Mechanism of depression as a risk factor in the development of Alzheimer's disease: the function of AQP4 and the glymphatic system. Psychopharmacology (Berl) 234:365-379.

[24]Mestre H, Mori Y, and Nedergaard M (2020) The Brain's Glymphatic System: Current Controversies. Trends Neurosci 43:458-466.

[25]Rasmussen R, O'Donnell J, Ding F, and Nedergaard M (2020) Interstitial ions: A key regulator of state-dependent neural activity? Prog Neurobiol 193:101802.

[26] Augusto-Oliveira M, Arrifano GP, Takeda PY, Lopes-Araújo A, Santos-Sacramento L, Anthony DC, Verkhratsky A, Crespo-Lopez ME (2020) Astroglia-specific contributions to the regulation of synapses, cognition and behaviour. Neurosci Biobehav Rev 118:331-357.

[27]Zhao Z, Nelson AR, Betsholtz C, Zlokovic BV (2015) Establishment and Dysfunction of the Blood-Brain Barrier. Cell 163:1064-1078.

[28] Stockmeier CA, Mahajan GJ, Konick LC, Overholser JC, Jurjus GJ, Meltzer HY, Uylings HB, Friedman L, Rajkowska G (2004) Cellular changes in the postmortem hippocampus in major depression. Biol Psychiatry 56:640-650.

[29]Chandley MJ, Szebeni K, Szebeni A, Crawford J, Stockmeier CA, Turecki G, Miguel-Hidalgo JJ, Ordway GA (2013) Gene expression deficits in pontine locus coeruleus astrocytes in men with major depressive disorder. J Psychiatry Neurosci 38:276-284.

[30]Rajkowska G, and Stockmeier, CA (2013) Astrocyte pathology in major depressive disorder: insights from human postmortem brain tissue. Curr Drug Targets 14:1225-1236.

[31]Rajkowska G, Legutko B, Moulana M, Syed M, Romero DG, Stockmeier CA, Miguel-Hidalgo JJ (2018) Astrocyte pathology in the ventral prefrontal white matter in depression. J Psychiatr Res 102:150-158.

[32]Cui Y, Yang Y, Ni Z, Dong Y, Cai G, Foncelle A, Ma S, Sang K, Tang S, Li Y, Shen Y, Berry H, Wu S, Hu H (2018) Astroglial Kir4.1 in the lateral habenula 
drives neuronal bursts in depression. Nature 554:323-327.

[33]Verkhratsky A, Parpura V (2016) Astrogliopathology in neurological, neurodevelopmental and psychiatric disorders. Neurobiol Dis 85:254-261.

[34]Czéh B, Nagy SA (2018) Clinical Findings Documenting Cellular and Molecular Abnormalities of Glia in Depressive Disorders. Front Mol Neurosci 11:56.

[35]Cotter D, Mackay D, Chana G, Beasley C, Landau S, Everall IP (2002) Reduced neuronal size and glial cell density in area 9 of the dorsolateral prefrontal cortex in subjects with major depressive disorder. Cereb Cortex 12:386-394.

[36]Rajkowska G, Miguel-Hidalgo JJ, Wei J, Dilley G, Pittman SD, Meltzer HY, Overholser JC, Roth BL, Stockmeier CA (1999) Morphometric evidence for neuronal and glial prefrontal cell pathology in major depression. Biol Psychiatry 45:1085-1098.

[37] Ongür D, Drevets WC, Price JL (1998) Glial reduction in the subgenual prefrontal cortex in mood disorders. Proc Natl Acad Sci USA 95:13290-13295.

[38]Cotter D, Mackay D, Landau S, Kerwin R, Everall I (2001) Reduced glial cell density and neuronal size in the anterior cingulate cortex in major depressive disorder. Arch Gen Psychiatry 58:545-553.

[39] Gittins RA, Harrison PJ (2011) A morphometric study of glia and neurons in the anterior cingulate cortex in mood disorder. J Affect Disord 133:328-332.

[40]Bowley MP, Drevets WC, Ongür D, Price JL (2002) Low glial numbers in the amygdala in major depressive disorder. Biol Psychiatry 52:404-412.

[41]Czéh B, Simon M, Schmelting B, Hiemke C, Fuchs E (2006) Astroglial plasticity in the hippocampus is affected by chronic psychosocial stress and concomitant fluoxetine treatment. Neuropsychopharmacology 31:1616-1626.

[42]Braun K, Antemano R, Helmeke C, Büchner M, Poeggel G (2009) Juvenile separation stress induces rapid region- and layer-specific changes in S100ss- and glial fibrillary acidic protein-immunoreactivity in astrocytes of the rodent medial prefrontal cortex. Neuroscience 160:629-638.

[43]Barley K, Dracheva S, Byne W (2009) Subcortical oligodendrocyte- and astrocyte-associated gene expression in subjects with schizophrenia, major 
depression and bipolar disorder. Schizophr Res 112:54-64.

[44]Bernard R, Kerman IA, Thompson RC, Jones EG, Bunney WE, Barchas JD, Schatzberg AF, Myers RM, Akil H, Watson SJ (2011) Altered expression of glutamate signaling, growth factor, and glia genes in the locus coeruleus of patients with major depression. Mol Psychiatry 16:634-646.

[45] Sequeira A, Mamdani F, Ernst C, Vawter MP, Bunney WE, Lebel V, Rehal S, Klempan T, Gratton A, Benkelfat C, Rouleau GA, Mechawar N, Turecki G (2009) Global brain gene expression analysis links glutamatergic and GABAergic alterations to suicide and major depression. PLoS One 4:e6585.

[46] Sun JD, Liu Y, Yuan YH, Li J, Chen NH (2012) Gap junction dysfunction in the prefrontal cortex induces depressive-like behaviors in rats. Neuropsychopharmacology 37:1305-1320.

[47]Bechtholt-Gompf AJ, Walther HV, Adams MA, Carlezon WA Jr, Ongür D, Cohen BM (2010) Blockade of astrocytic glutamate uptake in rats induces signs of anhedonia and impaired spatial memory. Neuropsychopharmacology 35:2049-2059.

[48]Banasr M, Duman RS (2008) Glial loss in the prefrontal cortex is sufficient to induce depressive-like behaviors. Biol Psychiatry 64:863-870.

[49] Verkhratsky A, Rodríguez JJ, Steardo L (2014) Astrogliopathology: a central element of neuropsychiatric diseases? Neuroscientist 20:576-588.

[50]Holden C (2003) Psychiatric drugs. Excited by glutamate. Science 300:1866-1868.

[51] Şengül B, Dursun E, Verkhratsky A, Gezen-Ak D (2021) Overexpression of $\alpha$-Synuclein Reorganises Growth Factor Profile of Human Astrocytes. Mol Neurobiol 58:184-203.

[52]Rudge JS, Alderson RF, Pasnikowski E, McClain J, Ip NY, Lindsay RM (1992) Expression of Ciliary Neurotrophic Factor and the Neurotrophins-Nerve Growth Factor, Brain-Derived Neurotrophic Factor and Neurotrophin 3-in Cultured Rat Hippocampal Astrocytes. Eur J Neurosci 4:459-471.

[53]Ijichi A, Sakuma S, Tofilon PJ (1995) Hypoxia-induced vascular endothelial 
growth factor expression in normal rat astrocyte cultures. Glia 14:87-93.

[54]Evans SJ, Choudary PV, Neal CR, Li JZ, Vawter MP, Tomita H, Lopez JF, Thompson RC, Meng F, Stead JD, Walsh DM, Myers RM, Bunney WE, Watson SJ, Jones EG, Akil H (2004) Dysregulation of the fibroblast growth factor system in major depression. Proc Natl Acad Sci USA 101:15506-15511.

[55]Allaman I, Fiumelli H, Magistretti PJ, Martin JL (2011) Fluoxetine regulates the expression of neurotrophic/growth factors and glucose metabolism in astrocytes. Psychopharmacology (Berl) 216:75-84.

[56]Quesseveur G, Gardier AM, Guiard BP (2013) The monoaminergic tripartite synapse: a putative target for currently available antidepressant drugs. Curr Drug Targets 14:1277-12794.

[57]Tyler WJ, Pozzo-Miller LD (2001) BDNF enhances quantal neurotransmitter release and increases the number of docked vesicles at the active zones of hippocampal excitatory synapses. J Neurosci 21:4249-4258.

[58]Kim YK, Na KS, Myint AM, Leonard BE (2016) The role of pro-inflammatory cytokines in neuroinflammation, neurogenesis and the neuroendocrine system in major depression. Prog Neuropsychopharmacol Biol Psychiatry 64:277-84.

[59] Troubat R, Barone P, Leman S, Desmidt T, Cressant A, Atanasova B, Brizard B, El Hage W, Surget A, Belzung C, Camus V (2020) Neuroinflammation and depression: A review. Epub ahead of print.

[60]Guo T, Guo Z, Yang X, Sun L, Wang S, Yingge A, He X, Ya T (2014) The Alterations of IL-1Beta, IL-6, and TGF-Beta Levels in Hippocampal CA3 Region of Chronic Restraint Stress Rats after Electroacupuncture (EA) Pretreatment. Evid Based Complement Alternat Med 2014:369158.

[61]Christian SL, Berry MD (2018) Trace Amine-Associated Receptors as Novel Therapeutic Targets for Immunomodulatory Disorders. Front Pharmacol 9:680.

[62]Ransohoff RM, Tani M (1998) Do chemokines mediate leukocyte recruitment in post-traumatic CNS inflammation? Trends Neurosci 21:154-159.

[63] Torres-Platas SG, Cruceanu C, Chen GG, Turecki G, Mechawar N (2014) Evidence for increased microglial priming and macrophage recruitment in the 
dorsal anterior cingulate white matter of depressed suicides. Brain Behav Immun 42:50-59.

[64]Panenka W, Jijon H, Herx LM, Armstrong JN, Feighan D, Wei T, Yong VW, Ransohoff RM, MacVicar BA (2001) P2X 7 -like receptor activation in astrocytes increases chemokine monocyte chemoattractant protein-1 expression via mitogen-activated protein kinase. J Neurosci 21:7135-7142.

[65]Iwata M, Ota KT, Li XY, Sakaue F, Li N, Dutheil S, Banasr M, Duric V, Yamanashi T, Kaneko K, Rasmussen K, Glasebrook A, Koester A, Song D, Jones KA, Zorn S, Smagin G, Duman RS (2016) Psychological Stress Activates the Inflammasome via Release of Adenosine Triphosphate and Stimulation of the Purinergic Type $2 \mathrm{X}_{7}$ Receptor. Biol Psychiatry 80:12-22.

[66]Metzger MW, Walser SM, Dedic N, Aprile-Garcia F, Jakubcakova V, Adamczyk M, Webb KJ, Uhr M, Refojo D, Schmidt MV, Friess E, Steiger A, Kimura M, Chen A, Holsboer F, Arzt E, Wurst W, Deussing JM (2017) Heterozygosity for the Mood Disorder-Associated Variant Gln460Arg Alters P2X Receptor Function and Sleep Quality. J Neurosci 37:11688-11700.

[67]Liu Y, Ding XF, Wang XX, Zou XJ, Li XJ, Liu YY, Li J, Qian XY, Chen JX (2019) Xiaoyaosan exerts antidepressant-like effects by regulating the functions of astrocytes and EAATs in the prefrontal cortex of mice. BMC Complement Altern Med 19:215.

[68]Pazini FL, Cunha MP, Azevedo D, Rosa JM, Colla A, de Oliveira J, Ramos-Hryb AB, Brocardo PS, Gil-Mohapel J, Rodrigues ALS (2017) Creatine Prevents Corticosterone-Induced Reduction in Hippocampal Proliferation and Differentiation: Possible Implication for Its Antidepressant Effect. Mol Neurobiol 54:6245-6260.

[69] Shu X, Sun Y, Sun X, Zhou Y, Bian Y, Shu Z, Ding J, Lu M, Hu G (2019) The effect of fluoxetine on astrocyte autophagy flux and injured mitochondria clearance in a mouse model of depression. Cell Death Dis 10:577.

[70]Zhao Y, Lin Z, Chen L, Ouyang L, Gu L, Chen F, Zhang Q (2018) Hippocampal astrocyte atrophy in a mouse depression model induced by corticosterone is 
reversed by fluoxetine instead of benzodiazepine diazepam. Prog Neuropsychopharmacol Biol Psychiatry 83:99-109.

[71]Dong S, Jiang HL, Wang Y, Lu J, Chang L, Zhang P, Xin SC, Tu Y (2018) Effect of Acupuncture on Expression of Glial Fibrillary Acidic Protein in Hippocampus and Prefrontal Cortex and Serum Interleukin-10 in Chronic Restraint Stress Depression Rats. Zhen Ci Yan Jiu 43:209-214.

[72]Chen L, Wang X, Lin ZX, Dai JG, Huang YF, Zhao YN (2017) Preventive Effects of Ginseng Total Saponins on Chronic Corticosterone-Induced Impairment in Astrocyte Structural Plasticity and Hippocampal Atrophy. Phytother Res. $31: 1341-1348$.

[73] Ayuob NN, Ali SS, Suliaman M, El Wahab MGA, Ahmed SM (2016) The antidepressant effect of musk in an animal model of depression: a histopathological study. Cell Tissue Res 366:271-284.

[74]Pan Y, Chen XY, Zhang QY, Kong LD (2014) Microglial NLRP3 inflammasome activation mediates IL-1 $\beta$-related inflammation in prefrontal cortex of depressive rats. Brain Behav Immun 41:90-100.

[75]Li B, Dong L, Wang B, Cai L, Jiang N, Peng L (2012) Cell type-specific gene expression and editing responses to chronic fluoxetine treatment in the in vivo mouse brain and their relevance for stress-induced anhedonia. Neurochem Res. $37: 2480-2495$.

[76]Dong L, Li B, Verkhratsky A, Peng L (2015) Cell type-specific in vivo expression of genes encoding signalling molecules in the brain in response to chronic mild stress and chronic treatment with fluoxetine. Psychopharmacology (Berl) $232: 2827-2835$

[77]Bule M, Abdurahman A, Nikfar S, Abdollahi M, Amini M (2019) Antidiabetic effect of quercetin: A systematic review and meta-analysis of animal studies. Food Chem Toxicol 125:494-502.

[78]Kumar M, Bajpai R, Shaik AR, Srivastava S, Vohora D (2020) Alliance between selective serotonin reuptake inhibitors and fracture risk: an updated systematic review and meta-analysis. Eur J Clin Pharmacol 76:1373-1392. 
[79]Hirst WD, Cheung NY, Rattray M, Price GW, Wilkin GP (1998) Cultured astrocytes express messenger RNA for multiple serotonin receptor subtypes, without functional coupling of $5-\mathrm{HT}_{1}$ receptor subtypes to adenylyl cyclase. Brain Res Mol Brain Res 61:90-99.

[80]Hirst WD, Price GW, Rattray M, Wilkin GP (1997) Identification of 5-hydroxytryptamine receptors positively coupled to adenylyl cyclase in rat cultured astrocytes. Br J Pharmacol 120:509-515.

[81]Meuser T, Pietruck C, Gabriel A, Xie GX, Lim KJ, Pierce Palmer P (2002) 5-HT7 receptors are involved in mediating 5-HT-induced activation of rat primary afferent neurons. Life Sci 71:2279-2289.

[82]Merzak A, Koochekpour S, Fillion MP, Fillion G, Pilkington GJ (1996) Expression of serotonin receptors in human fetal astrocytes and glioma cell lines: a possible role in glioma cell proliferation and migration. Brain Res Mol Brain Res 41:1-7.

[83]Eriksen JL, Gillespie R, Druse MJ (2002) Effects of ethanol and 5-HT1A agonists on astroglial S100B. Brain Res Dev Brain Res 139:97-105.

[84] Schroeter ML, Abdul-Khaliq H, Diefenbacher A, Blasig IE (2002) S100B is increased in mood disorders and may be reduced by antidepressive treatment. Neuroreport 13:1675-1678.

[85]Rothermundt M, Arolt V, Wiesmann M, Missler U, Peters M, Rudolf S, Kirchner $\mathrm{H}$ (2001) S-100B is increased in melancholic but not in non-melancholic major depression. J Affect Disord 66:89-93.

[86] Stroth N, Svenningsson P (2015) S100B interacts with the serotonin 5- $\mathrm{HT}_{7}$ receptor to regulate a depressive-like behavior. Eur Neuropsychopharmacol $25: 2372-2380$.

[87]Asaoka N, Nagayasu K, Nishitani N, Yamashiro M, Shirakawa H, Nakagawa T, Kaneko S (2015) Olanzapine augments the effect of selective serotonin reuptake inhibitors by suppressing GABAergic inhibition via antagonism of 5- $\mathrm{HT}_{6}$ receptors in the dorsal raphe nucleus. Neuropharmacology 95:261-268.

[88]Daniele S, Zappelli E, and Martini C (2015) Trazodone regulates 
neurotrophic/growth factors, mitogen-activated protein kinases and lactate release in human primary astrocytes. Journal of Neuroinflammation 12:255

[89]Li B, Zhang S, Zhang $\mathrm{H}$, Nu W, Cai L, Hertz L, Peng L (2008) Fluoxetine-mediated $5-\mathrm{HT}_{2 \mathrm{~B}}$ receptor stimulation in astrocytes causes EGF receptor transactivation and ERK phosphorylation. Psychopharmacology (Berl) 201:443-458

[90]Peng L, Gu L, Li B, Hertz L (2014) Fluoxetine and all other SSRIs are 5-HT2B Agonists - Importance for their Therapeutic Effects. Curr Neuropharmacol $12: 365-379$.

[91]Roth BL, Willins DL, Kristiansen K, Kroeze WK (1998) 5-Hydroxytryptamine2-family receptors (5-hydroxytryptamine2A, 5-hydroxytryptamine2B, 5-hydroxytryptamine2C): where structure meets function. Pharmacol Ther 79:231-257.

[92]Verkhratsky A, Rodríguez JJ, Parpura V (2012) Calcium signalling in astroglia. Mol Cell Endocrinol 353:45-56.

[93]Verkhratsky A, Semyanov A, and Zorec R (2020) Physiology of astroglial excitability. Function 1, zqaa016, doi: 10.1093/function/zqaa016.

[94]Izumi Y, Hirata M, Hasuwa H, Iwamoto R, Umata T, Miyado K, Tamai Y, Kurisaki T, Sehara-Fujisawa A, Ohno S, Mekada E (1998) A metalloprotease-disintegrin, MDC9/meltrin-gamma/ADAM9 and PKCdelta are involved in TPA-induced ectodomain shedding of membrane-anchored heparin-binding EGF-like growth factor. EMBO J 17:7260-7272.

[95] Gechtman Z, Alonso JL, Raab G, Ingber DE, Klagsbrun M (1999) The shedding of membrane-anchored heparin-binding epidermal-like growth factor is regulated by the Raf/mitogen-activated protein kinase cascade and by cell adhesion and spreading. J Biol Chem 274:28828-28835.

[96]Peng L, Huang J (2012) Astrocytic 5-HT(2B) receptor as in vitro and in vivo target of SSRIs. Recent Pat CNS Drug Discov 7:243-253.

[97]Li B, Jia S, Yue T, Yang L, Huang C, Verkhratsky A, Peng L (2017) Biphasic Regulation of Caveolin-1 Gene Expression by Fluoxetine in Astrocytes: Opposite 
Effects of PI3K/AKT and MAPK/ERK Signaling Pathways on c-fos. Front Cell Neurosci 11:335.

[98]Li B, Zhang S, Li M, Hertz L, Peng L (2009) Chronic treatment of astrocytes with therapeutically relevant fluoxetine concentrations enhances cPLA2 expression secondary to 5- $\mathrm{HT}_{2 \mathrm{~B}}$-induced, transactivation-mediated ERK1/2 phosphorylation. Psychopharmacology (Berl) 207:1-12.

[99]Li X, Liang S, Li Z, Li S, Xia M, Verkhratsky A, Li B (2019) Leptin Increases Expression of 5-HT2B Receptors in Astrocytes Thus Enhancing Action of Fluoxetine on the Depressive Behavior Induced by Sleep Deprivation. Front Psychiatry 9:734.

[100] Karege F, Perroud N, Burkhardt S, Schwald M, Ballmann E, La Harpe R, Malafosse A (2007) Alteration in kinase activity but not in protein levels of protein kinase B and glycogen synthase kinase-3beta in ventral prefrontal cortex of depressed suicide victims. Biol Psychiatry 61:240-245.

[101] Diniz BS, Talib LL, Joaquim HP, de Paula VR, Gattaz WF, Forlenza OV (2011) Platelet GSK3B activity in patients with late-life depression: marker of depressive episode severity and cognitive impairment? World J Biol Psychiatry 12:216-222.

[102] Pláteník J, Fišar Z, Buchal R, Jirák R, Kitzlerová E, Zvěřová M, Raboch J (2014) GSK3 $\beta$, CREB, and BDNF in peripheral blood of patients with Alzheimer's disease and depression. Prog Neuropsychopharmacol Biol Psychiatry 50:83-93.

[103] Alttoa A, Kõiv K, Hinsley TA, Brass A, Harro J (2010) Differential gene expression in a rat model of depression based on persistent differences in exploratory activity. Eur Neuropsychopharmacol 20:288-300.

[104] Stephenson DT, Manetta JV, White DL, Chiou XG, Cox L, Gitter B, May PC, Sharp JD, Kramer RM, Clemens JA (1994) Calcium-sensitive cytosolic phospholipase A2 (cPLA2) is expressed in human brain astrocytes. Brain Res 637:97-105.

[105] Gopaldas M, Zanderigo F, Zhan S, Ogden RT, Miller JM, Rubin-Falcone H, Cooper TB, Oquendo MA, Sullivan G, Mann JJ, Sublette ME (2019) Brain serotonin transporter binding, plasma arachidonic acid and depression severity: A 
positron emission tomography study of major depression. J Affect Disord 257:495-503.

[106] Köhr G, Melcher T, Seeburg PH (1998) Candidate editases for GluR channels in single neurons of rat hippocampus and cerebellum. Neuropharmacology $37: 1411-1417$.

[107] Li B, Zhang S, Zhang H, Hertz L, Peng L (2011) Fluoxetine affects GluK2 editing, glutamate-evoked $\mathrm{Ca}(2+)$ influx and extracellular signal-regulated kinase phosphorylation in mouse astrocytes. J Psychiatry Neurosci 36:322-338.

[108] Yue T, Li B, Gu L, Huang J, Verkhratsky A, Peng L (2019) Ammonium induced dysfunction of 5-HT $2 \mathrm{~B}$ receptor in astrocytes. Neurochem Int 129:104479

[109] Li Z, Lu Y, Liang S, Li S, Chen B, Zhang M, Xia M, Guan D, Verkhratsky A, Li B (2020) Fluoxetine improves behavioural deficits induced by chronic alcohol treatment by alleviating RNA editing of $5-\mathrm{HT}_{2 \mathrm{C}}$ receptors. Neurochem Int 134:104689.

[110] Cao X, Li LP, Wang Q, Wu Q, Hu HH, Zhang M, Fang YY, Zhang J, Li SJ, Xiong WC, Yan HC, Gao YB, Liu JH, Li XW, Sun LR, Zeng YN, Zhu XH, Gao TM (2013) Astrocyte-derived ATP modulates depressive-like behaviors. Nat Med 19:773-777.

[111] Benca RM, Peterson MJ (2008) Insomnia and depression. Sleep Med 9 Suppl 1:S3-9.

[112] Xia M, Li X, Yang L, Ren J, Sun G, Qi S, Verkhratsky A, and Li B (2018) The ameliorative effect of fluoxetine on neuroinflammation induced by sleep deprivation. J Neurochem 146: 63-75.

[113] Xia M, Li Z, Li S, Liang S, Li X, Chen B, Zhang M, Dong C, Verkhratsky A, Guan D, Li B (2020) Sleep Deprivation Selectively Down-Regulates Astrocytic 5-HT2B Receptors and Triggers Depressive-Like Behaviors via Stimulating $\mathrm{P}_{2} \mathrm{X}_{7}$ Receptors in Mice. Neurosci Bull 36:1259-1270.

[114] Li B, Qi S, Sun G, Yang L, Han J, Zhu Y, Xia M (2016) Leptin suppresses adenosine triphosphate-induced impairment of spinal cord astrocytes. J Neurosci Res 94:924-935. 
[115] Molendijk ML, Spinhoven P, Polak M, Bus BA, Penninx BW, Elzinga BM (2014) Serum BDNF concentrations as peripheral manifestations of depression: evidence from a systematic review and meta-analyses on 179 associations $(\mathrm{N}=9484)$. Mol Psychiatry 19:791-800.

[116] de Pins B, Cifuentes-Díaz C, Farah AT, López-Molina L, Montalban E, Sancho-Balsells A, López A, Ginés S, Delgado-García JM, Alberch J, Gruart A, Girault JA, Giralt A (2019) Conditional BDNF Delivery from Astrocytes Rescues Memory Deficits, Spine Density, and Synaptic Properties in the 5xFAD Mouse Model of Alzheimer Disease. J Neurosci 39:2441-2458.

[117] Kowiański P, Lietzau G, Czuba E, Waśkow M, Steliga A, Moryś J (2018) BDNF: A Key Factor with Multipotent Impact on Brain Signaling and Synaptic Plasticity. Cell Mol Neurobiol 38:579-593.

[118] Geerlings MI, den Heijer T, Koudstaal PJ, Hofman A, Breteler MM (2008) History of depression, depressive symptoms, and medial temporal lobe atrophy and the risk of Alzheimer disease. Neurology 70:1258-1264.

[119] Werner FM, Covenas R (2016) Serotonergic Drugs: Agonists/Antagonists at Specific Serotonergic Subreceptors for the Treatment of Cognitive, Depressant and Psychotic Symptoms in Alzheimer's Disease. Curr Pharm Des 22:2064-2071.

[120] Liang S, Lu Y, Li Z, Li S, Chen B, Zhang M, Chen B, Ji M, Gong W, Xia M, Verkhratsky A, Wu X, Li B (2020) Iron Aggravates the Depressive Phenotype of Stressed Mice by Compromising the Glymphatic System. Neurosci Bull $36: 1542-1546$.

[121] Wang X, Lou N, Eberhardt A, Yang Y, Kusk P, Xu Q, Förstera B, Peng S, Shi M, Ladrón-de-Guevara A, Delle C, Sigurdsson B, Xavier ALR, Ertürk A, Libby RT, Chen L, Thrane AS, Nedergaard M (2020) An ocular glymphatic clearance system removes $\beta$-amyloid from the rodent eye. Sci Transl Med 12:eaaw3210.

[122] Kong H, Sha LL, Fan Y, Xiao M, Ding JH, Wu J, Hu G (2009) Requirement of AQP4 for antidepressive efficiency of fluoxetine: implication in adult hippocampal neurogenesis. Neuropsychopharmacology 34:1263-1276.

[123]Di Benedetto B, Malik VA, Begum S, Jablonowski L, Gómez-González GB, 26 
Neumann ID, Rupprecht R (2016) Fluoxetine Requires the Endfeet Protein Aquaporin-4 to Enhance Plasticity of Astrocyte Processes. Front Cell Neurosci $10: 8$. 

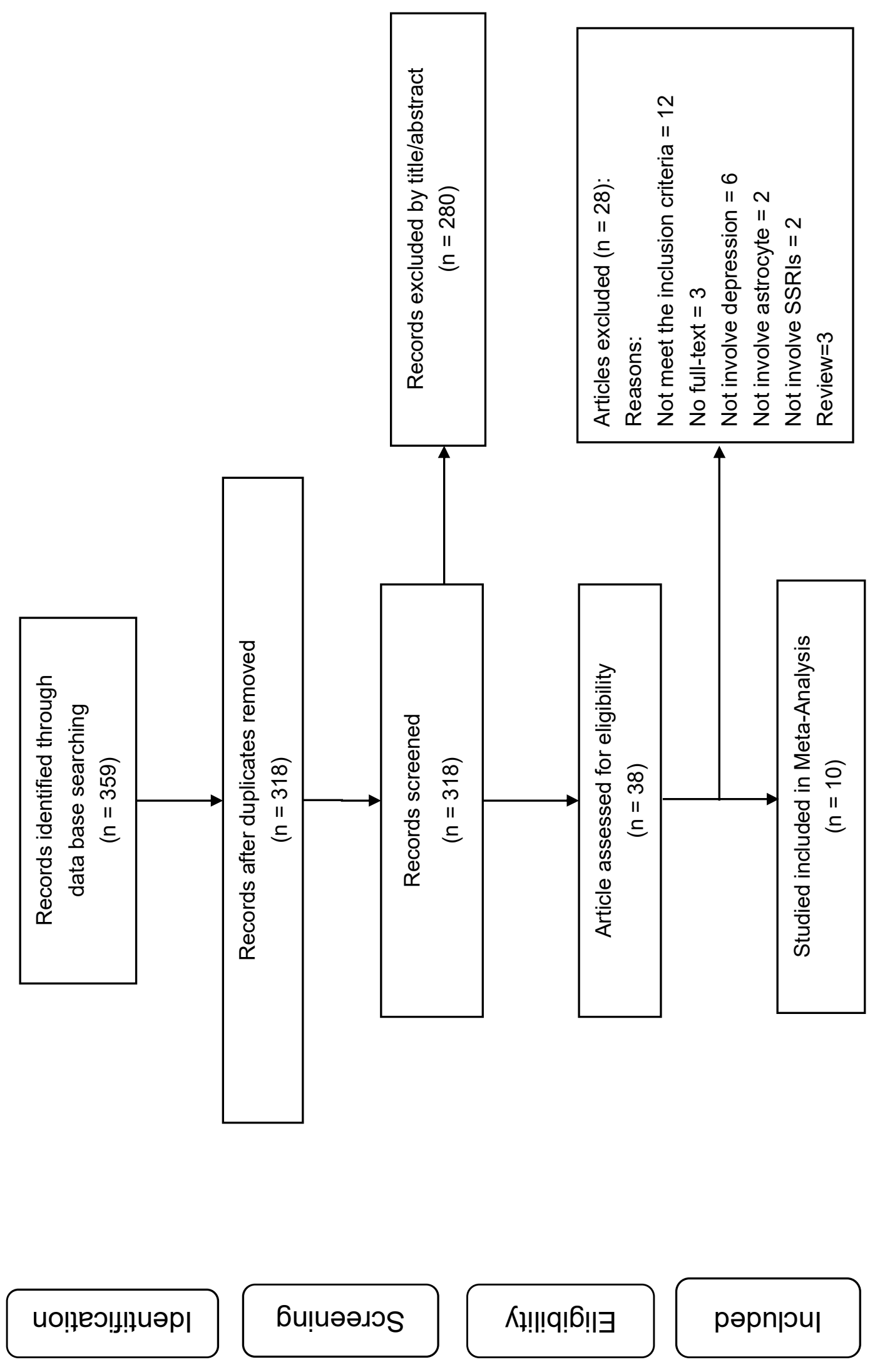


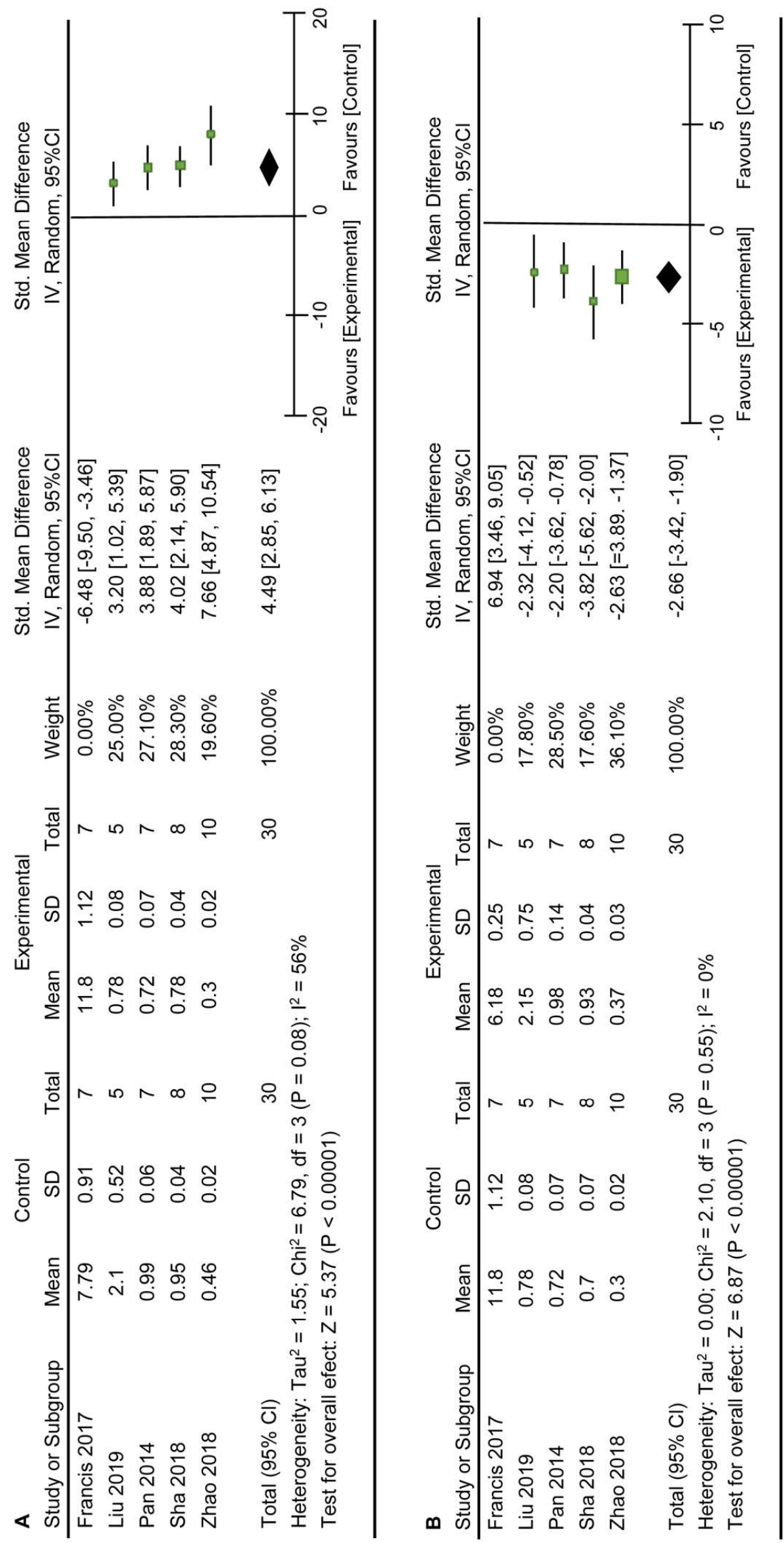






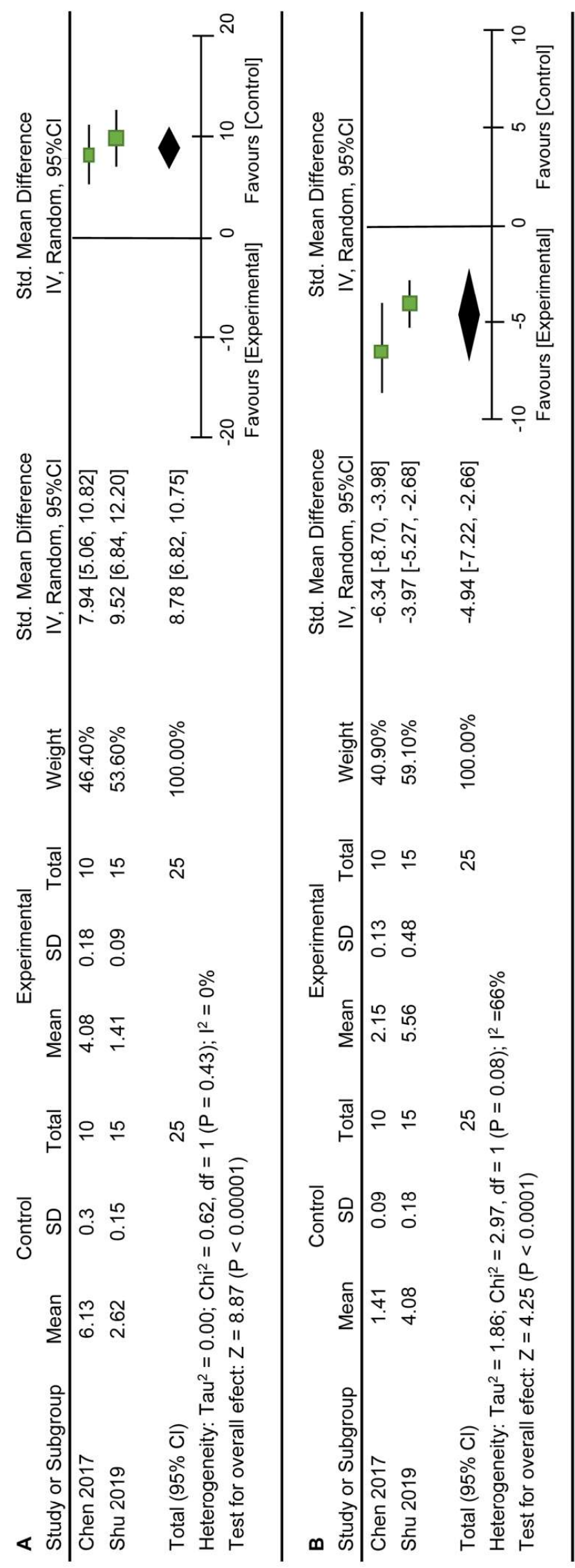

$m_{1}$
인 




$\nabla_{1}$
만 


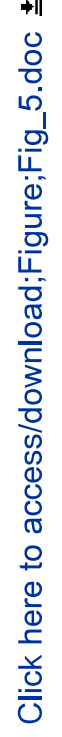

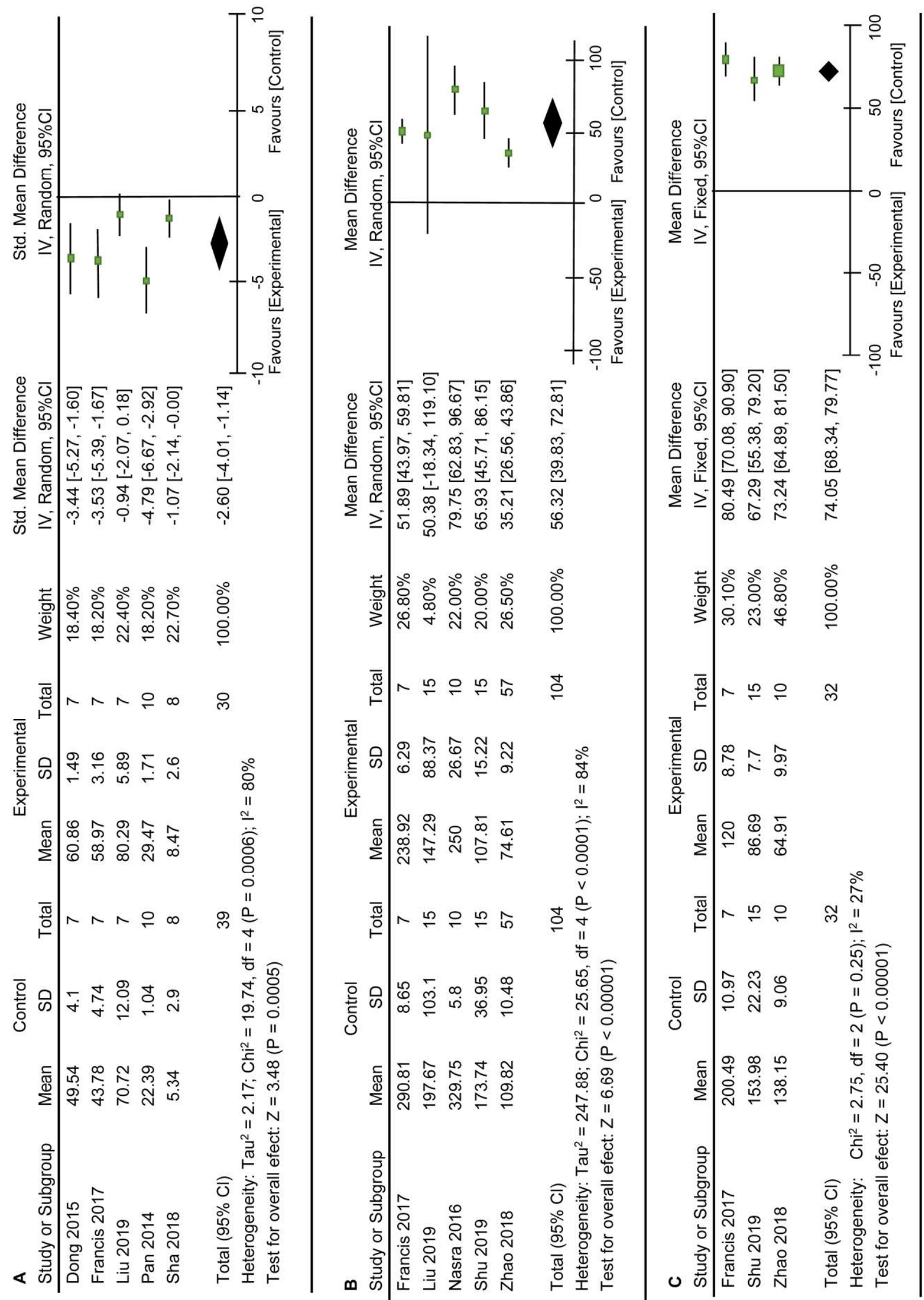




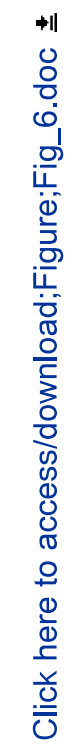

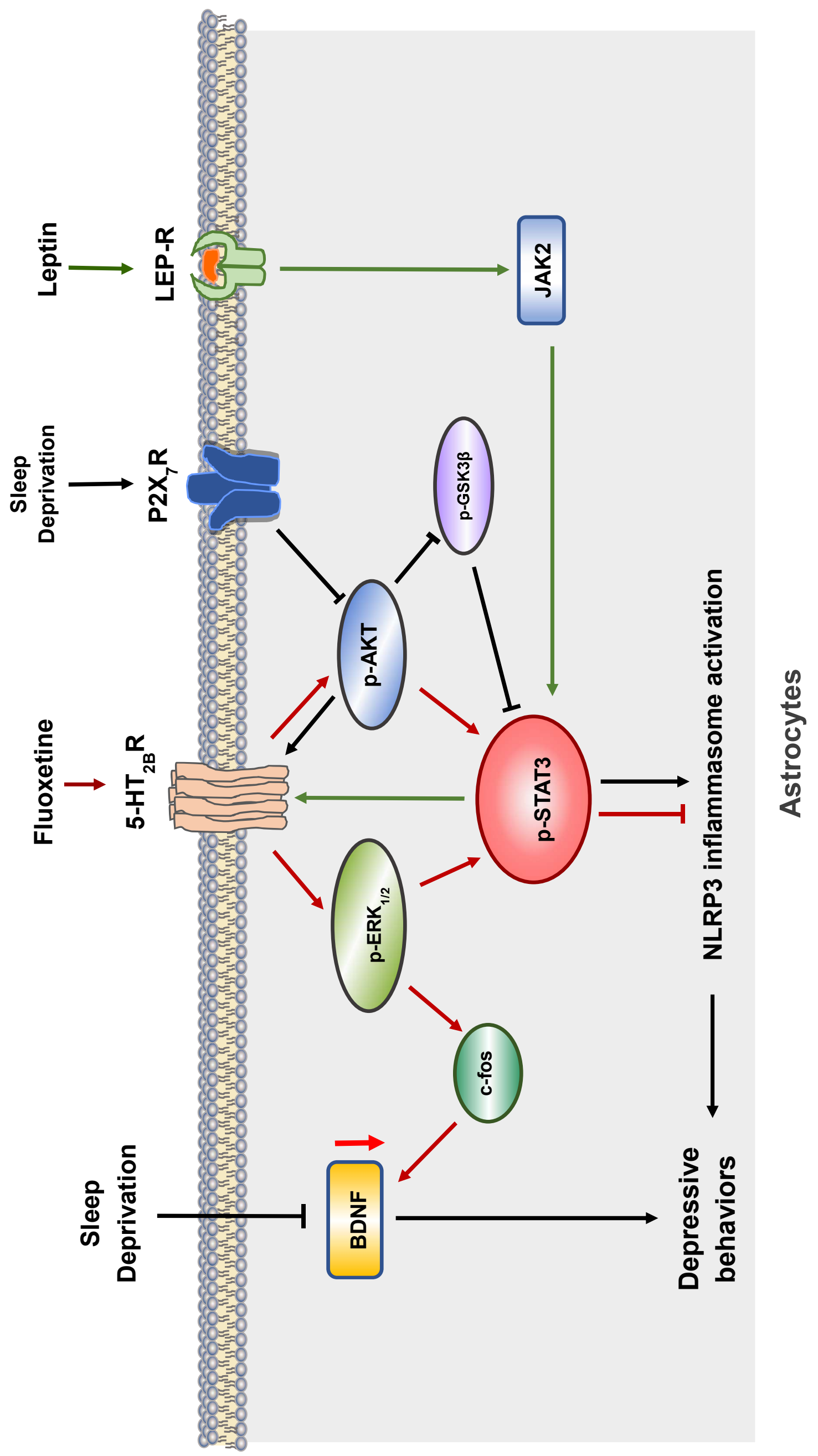









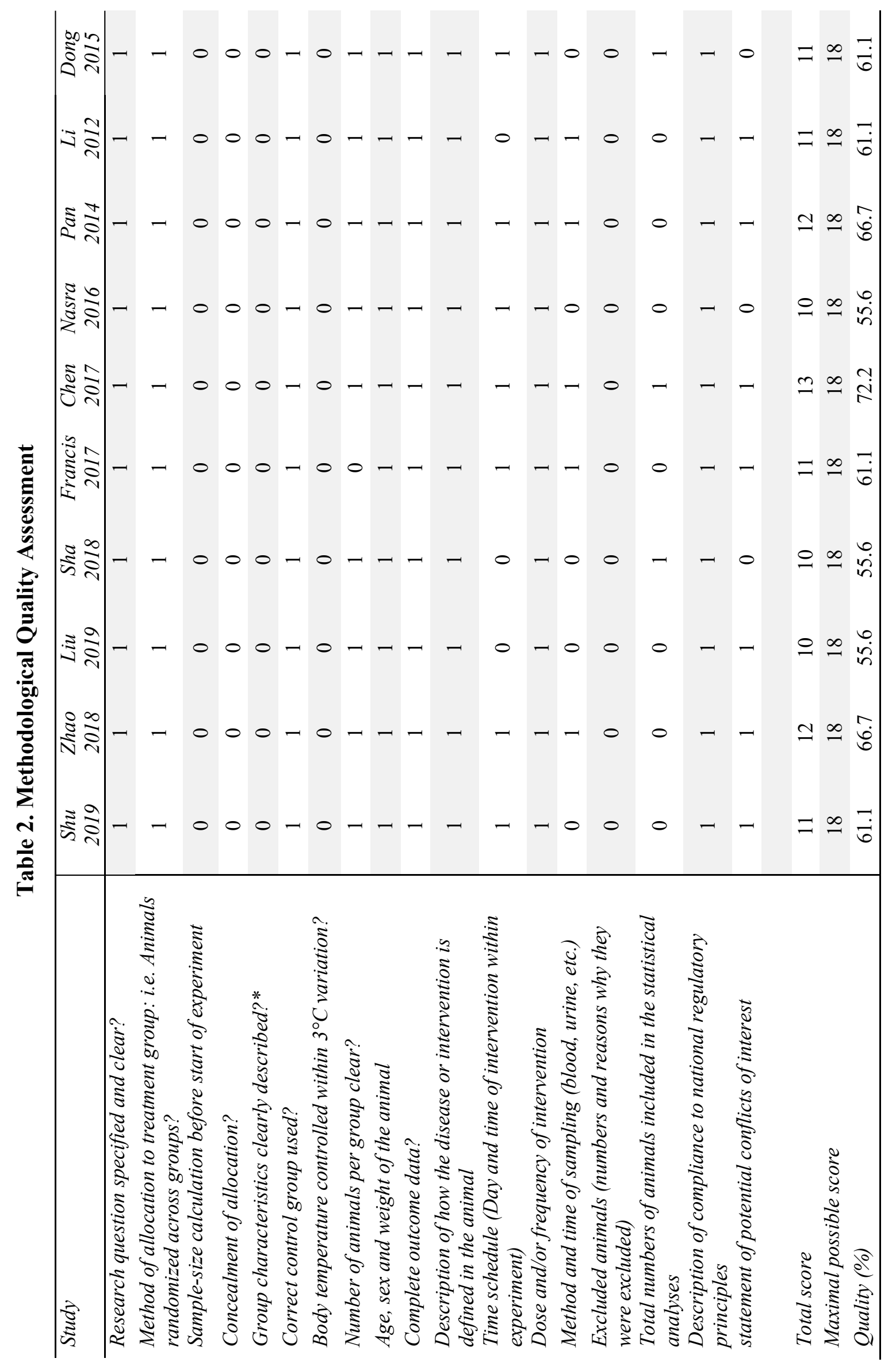




\section{Click here to access/download Supplementary material Supplement Material.doc}

